Discussion Paper No. 855

\title{
GENDER IMBALANCE AT BIRTH AND PARENTS' ANXIETY ABOUT OLD AGE IN CHINA
}

\author{
Yoshihiko Kadoya \\ Ting Yin
}

August 2012

The Institute of Social and Economic Research
Osaka University
6-1 Mihogaoka, Ibaraki, Osaka 567-0047, Japan 


\title{
Gender imbalance at birth and parents' anxiety about old age in China*
}

\author{
Yoshihiko Kadoya $^{\dagger}$ \\ Institute of Social and Economic Research, Osaka University \\ Ting Yin \\ Institute of Social and Economic Research, Osaka University
}

\begin{abstract}
Chinese parents prefer to have sons as they depend on their sons for support in old age, according to most of the literature. This paper uses the Preference Parameters Study, which randomly interviewed individuals in six major cities in China in 2011, to present empirical evidence about the possible cause of the problematic gender imbalance at birth in China. From the dataset, this paper compares sons' and daughters' commitment to parental care from a selection of respondents who were married, aged 20-70, had at least one living parent, and had no missing answers to the interview questions. The results indicate that Chinese sons (and their wives) are more likely, compared to daughters (and their husbands), to be primary caregivers for parents. Nonetheless, parents' dependency on their children would not necessarily decrease with social security, although children with highly educated spouses appear to present an exception. The current study supports the initial claim found in literature; however, the solution to the gender imbalance at birth in China may not be the development of a social security system.
\end{abstract}

Key Words: gender imbalance, anxiety about old age, family caregiving, son preference, China

JEL classification: P29, J16

\footnotetext{
* This research used micro data from the Preference Parameters Study of Osaka University's 21st Century COE Program 'Behavioral Macrodynamics Based on Surveys and Experiments' and its Global COE project 'Human Behavior and Socioeconomic Dynamics.' We acknowledge the program/project's contributors: Yoshiro Tsutsui, Fumio Ohtake, and Shinsuke Ikeda. We thank Fumio Ohtake, Masaru Sasaki, Charles Yuji Horioka, Midori Wakabayashi, Wataru Kureishi, and the other seminar participants at Osaka University, Japan.

†Corresponding author: Yoshihiko Kadoya, Institute of Social and Economic Research, Osaka University, Mihogaoka 6-1, Ibaraki, Osaka 567-0047, Japan. Phone: +81-6-6879-8573. E-mail: kadoya@iser.osaka-u.ac.jp
} 


\section{Introduction}

Does the anxiety about old age cause the gender imbalance in China? Chinese parents prefer to have sons as they depend on their sons for support in old age, mainly because of the absence of well-functioning social insurance programs (Chan, Yip, Ng et al., 2002; Chen, Li, \& Meng, 2012; and Wei \& Zhang, 2011). There is, however, no empirical evidence that a) Chinese sons take care of their parents more than daughters do, or b) the development of social security would ease the gender imbalance at birth. This research first tests the hypothesis that Chinese sons take care of their parents more than Chinese daughters do by investigating Chinese household survey data, and then considers whether the development of social security would solve the problematic gender imbalance in China.

Traditionally, Chinese parents have preferred boys and the population of China reflects a significant gender imbalance that favors males (Coale, 1991). As reported in censuses, gender imbalance (male to female) at birth rose from 1.076 in 1982 to 1.223 in 2008 (National Bureau of Statistics of China, 2010). Sex selective abortion that has become possible due to modern science has accelerated such gender imbalance (Chen, Li, \& Meng, 2012). Hesketh and Xing (2006) pointed out that the abnormal gender ratio in the population may cause social problems in the future, increasing levels of violence as many young males fail to find partners.

Much of the literature considers parents' anxieties about old age as a major reason for Chinese parents preferring boys. Traditionally, the Chinese believe that once daughters are married, they belong to their husbands and their husbands' families; thus, daughters' families-of-origin, especially their parents, rely heavily on their sons and daughters-in-law for security in old age (Chan, Yip, Ng et al., 2002; Chen, Li, \& Meng, 2012; and Wei \& Zhang, 2011). Recently, due to the government's one-child policy, most parents can have only one child. If the only child is a girl, her parents have no one to care for them in old age. Therefore, families place strong preference on male offspring.

There are some poorly supported, yet possible, rebuttals. First, one may claim that the male preference in China is a part of its traditional culture, 
not stemming just from the need for long-term care, but such traditional culture is not unique to China. Ancient Chinese, Egyptian, and Greek civilizations, for example, shared some practices and manipulations that they claimed to be effective in influencing the gender of a child before its birth (Chan, Yip, Ng et al., 2002). Such a male preference culture remains in today's world, to some extent due to the notion of "inheriting family history." In most countries, including the United Kingdom, Germany, France, the United States, Japan, and Korea, children usually carry their fathers' family names, not their mothers'. Yet, such male preference tradition does not affect the gender balance in most countries. Table 1 indicates the gender balance at birth by selected countries. Although the notion of "inheriting family history" is to some extent common in these countries, there is no other country that loses the gender balance as much as China.

Table 1: Gender-balance at birth and total fertility rate in selected countries

\begin{tabular}{|l|l|l|l|}
\hline & $\begin{array}{l}\text { Gender-balance (Male } \\
\text { to Female }) \text { at birth } \\
(2005-2010)\end{array}$ & $\begin{array}{l}\text { Total fertility rate } \\
(2010)\end{array}$ \\
\hline China & 1.19 & - & \\
\hline United Kingdom & 1.05 & 2.00 & \\
\hline Germany & 1.06 & 1.39 \\
\hline France & 1.05 & 2.01 \\
\hline United States & 1.05 & 1.93 \\
\hline Japan & 1.06 & 1.39 \\
\hline Korea, Republic of & 1.10 & 1.23 & \\
\hline
\end{tabular}

Source: For Gender-balance, World Bank (2012). For total fertility rate, Cabinet Office, Government of Japan (2012).

Second, one may think male preference results from China's introduction of its unique one-child policy, but the effect may be limited. Certainly, parents in China tend to be more selective on the gender of their child because they often have no second chance. Nonetheless, many parents in other countries, such as Germany, Japan, and Korea, cannot afford a second child either, due to socio-economic circumstances. Evidently, the total fertility rate of these countries indicates much less than two, yet these countries do not lose their 
gender balance at birth to the extent that China does.

A major difference between China and the others lies in the level of dependency on the son in old age: Chinese social security is very weak. Table 2 indicates workers' pension participation rates in selected countries. While the pension coverage rate is only 20 percent in China, the overages in most other countries are about 90 percent. Korea appears to be an exception, but the coverage is still more than double that in China. In addition, Table 3 shows that China has not yet developed the long-term care policies that other nations have already prepared. As the literature claims, therefore, Chinese parents most likely prefer boys because of the absence of a well-functioning social security system.

Table 2: Worker's Pension Program Participation Rates in Selected Countries

\begin{tabular}{|l|l|l|l|l|l|l|l|}
\hline & China & UK & Germany & France & US & Japan & Korea \\
\hline $\begin{array}{l}\text { Worker's } \\
\text { Raticipation }\end{array}$ & $20.7 \%$ & $92.3 \%$ & $87.6 \%$ & $87.9 \%$ & $92.1 \%$ & $95.2 \%$ & $49.5 \%$ \\
\hline Remarks & $\begin{array}{l}\text { Still under } \\
\text { development }\end{array}$ & $\begin{array}{l}\text { Compulsory } \\
\text { participation } \\
\text { for employees } \\
\text { and } \\
\text { self-employed } \\
\text { individuals }\end{array}$ & $\begin{array}{l}\text { Compulsory } \\
\text { participation } \\
\text { for employees } \\
\text { and some } \\
\text { types of } \\
\text { self-employed } \\
\text { individuals }\end{array}$ & $\begin{array}{l}\text { Compulsory } \\
\text { participation } \\
\text { for employees } \\
\text { and } \\
\text { self-employed } \\
\text { individuals }\end{array}$ & $\begin{array}{l}\text { Compulsory } \\
\text { participation } \\
\text { for employees } \\
\text { and } \\
\text { self-employed } \\
\text { individuals }\end{array}$ & $\begin{array}{l}\text { Universal } \\
\text { coverage }\end{array}$ & $\begin{array}{l}\text { Universal } \\
\text { coverage }\end{array}$ \\
\hline
\end{tabular}

Source: OECD (2007).

Table 3: Major Public Long-Term Care Programs Selected Countries

\begin{tabular}{|l|l|l|l|l|l|l|l|}
\hline & China & UK & Germany & France & US & Japan & Korea \\
\hline $\begin{array}{l}\text { Major Public } \\
\text { Long-Term } \\
\begin{array}{l}\text { Care } \\
\text { Program }\end{array}\end{array}$ & $\begin{array}{l}\text { Under- } \\
\text { development }\end{array}$ & $\begin{array}{l}\text { Social services/ } \\
\text { Social Security }\end{array}$ & $\begin{array}{l}\text { Social } \\
\text { Benefits } \\
\text { Long-Term } \\
\text { Care }\end{array}$ & $\begin{array}{l}\text { APA } \\
\text { (Universal) }\end{array}$ & $\begin{array}{l}\text { Medicaid } \\
\text { (Means-tested) }\end{array}$ & $\begin{array}{l}\text { Long-Term } \\
\text { Care } \\
\text { Insurance } \\
\text { (Universal) }\end{array}$ & $\begin{array}{l}\text { Long-Term } \\
\text { Care } \\
\text { Insurance } \\
\text { (Universal) }\end{array}$ \\
\hline
\end{tabular}

Source: OECD (2005) and Colombo F., Llena-Nazal A., Mercier J., \& Tjadens F. (2011).

The solution drawn from literature is that the development of the social security eases the gender-imbalance at birth in China. With well-functioning the social security, Chinese parents would become less dependent on their son. Many of them would not make "efforts" to choose to have a son. Consequently, the gender imbalance would be eased.

However, the argument has a critical weakness. The logic, based on the traditional assumption that Chinese sons take care of their parents more 
than Chinese daughters do, has no empirical evidence to support it. Most literature related to the gender imbalance issue builds arguments based on the assumption that Chinese sons provide better long-term care for parents. If the assumption were wrong, the cause of the gender imbalance in China would be unrelated to parental anxiety about old age. The conclusion, and the assumed solution, therefore, would address the wrong cause. In addition, even if the traditional assumption were correct in the past, there is no guarantee it is still right today. Some literature disagrees with the traditional assumption due to the recent transitions in the socio-economic environment. Davis (1993) and Zhan \& Montgomery (2003) claim a recent change of the gender role in elder care. Cooney \& Di (1999) report an increase in the number of parents cared for by daughters in the Shanghai area as opposed to daughters-in-law and sons. The basic assumption in gender imbalance issues in China now strongly requires national verification.

The primary purpose of this paper is to address the absence of empirical evidence. Testing the assumption that Chinese sons take care of their parents more than Chinese daughters do, this research proposes a basis for the cause of the gender imbalance issue in China and a possible solution to the issue.

\section{Data}

The data used in this research were from Osaka University's "Preference Parameters Study in China 2011.” The study conducted face-to-face interviews of individuals and households in six major cities, including Beijing, Shanghai, Guangzhou, Chengdu, Wuhan, and Shenyang, from December 23, 2010 to January 21, 2011. The target respondents were adults aged 20 to 70 years old. The sampling applied Multistage Sampling and Allocation Methods. The study first set predicted numbers of responses based on the target population in each district using the Statistical Yearbook. Then, the study randomly selected an area in each district. Finally, the study chose the interviewed individuals from families using the Kish Grid method. From the data set, the current research chose 454 observations who were married, had at least one living parent, and had no missing answers.

Collected in major Chinese cities only, the data unfortunately do not represent the entire 
nation of China. Representing the population of the six major cities, however, the dataset includes a significant part of the country. As mentioned earlier, Cooney \& Di (1999), who compared the number of parents cared for by sons and daughters, used data from Shanghai only. The current research, therefore, also contributes to a better understanding of the hypothesis that Chinese sons take care of their parents more than Chinese daughters do.

\section{Results}

\section{Simple Observation}

The primary question asked for this research was the following: Who will be the primary caregiver for your own father/mother when he/she needs long-term care? The choices were 1) you (respondent), 2) your spouse, 3) your brother/sister or your spouse's brother/sister, 4) the spouse of the parent requiring care, 5) other family member, 6) nursing home or assisted living home, 7) home-helper, or 8) other. The respondent was required to make only one choice for each parent. Table 4 indicates the answers. The responses for fathers and mothers are uneven because some respondents had only one living parent.

The answers to the question have four implications for parent-child relationships in the context of long-term care in China. First, Chinese parents are heavily dependent on their children for their long-term care. The answer choices from 1 to 3 indicate a child(ren), including a child(ren)'s spouse(s), primarily providing care for the parent(s). The sub-total of the total category in Table 4 shows that 90 percent of parents are dependent on their child(ren) for required care. 
Table 4: Primary Care Giver for Parents According to the Respondent's Gender

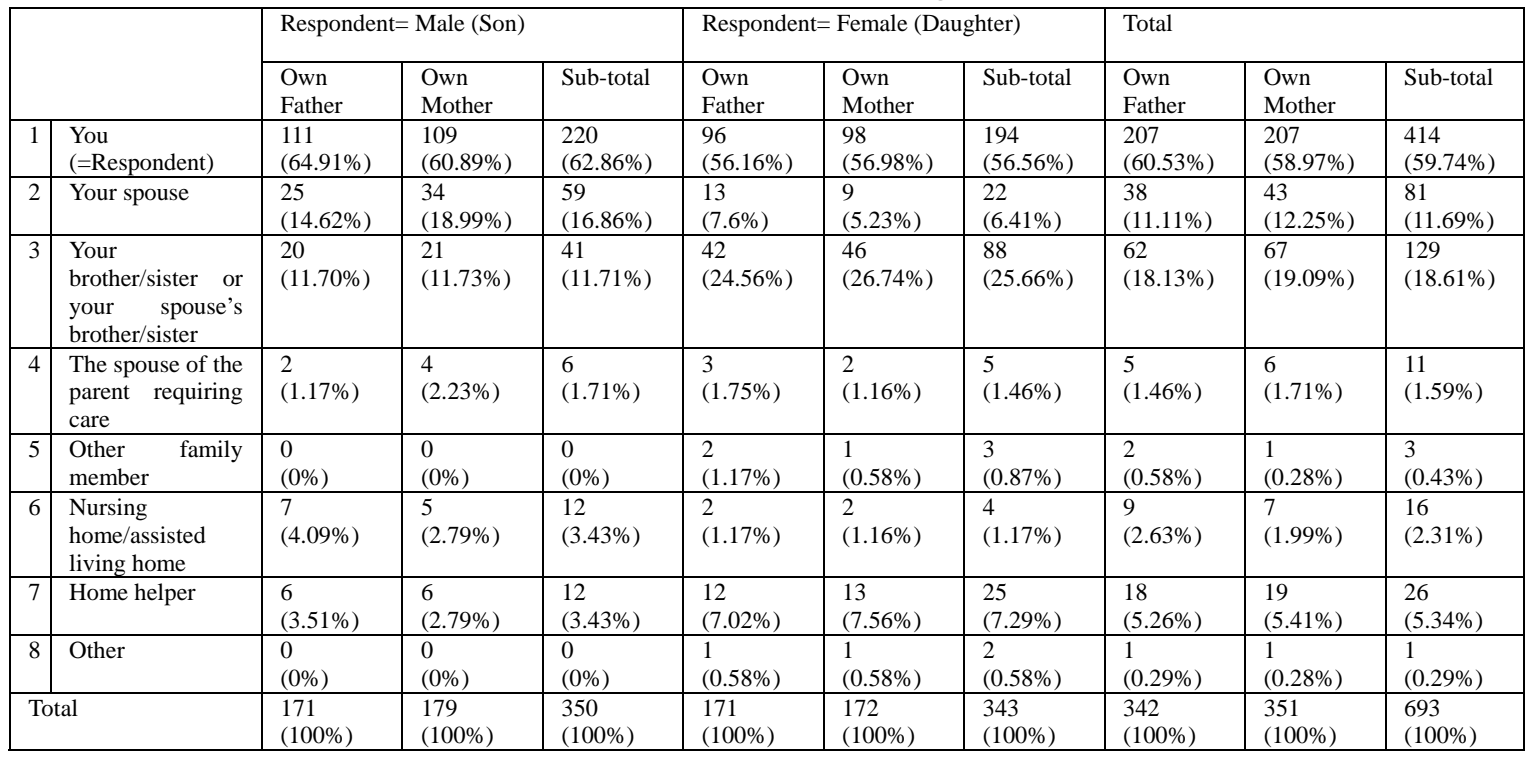

Second, Chinese parents seem to be more dependent on their sons. Choice 1 for male respondents (sons) occupies more than 60 percent, whereas that of female respondents (daughters) is about 56 percent. Including choice 2, which is the respondent's spouse, the dependency on sons increases to nearly 80 percent, whereas that on daughters is only about 63 percent. As predicted in the literature, Chinese parents rely on their sons and daughters-in-law for long-term care.

Third, parents that have daughters may have difficulties finding caregivers in the future. The female respondents in this research expect their siblings or the siblings' spouses to provide long-term care for their parents. In fact, almost 25 percent of female respondents chose choice 3 , which is more than double the 11.7 percent of male respondents who made this choice. However, choice 3 is possible only when female respondents have siblings. As mentioned earlier, the Chinese government introduced the one-child policy in 1979. Targeting those aged 20-69 years old, this research included many respondents born prior to 1979. It is clear, however, that younger generations will not often have siblings and the parents that have daughters will suffer more than those who have sons.

Fourth, it is unknown from the results if the development of social security would ease the sons' preference. As seen earlier, the parents that have 
daughters rely more on their other children, not necessarily on professional care, indicated by choices 6 and 7. As choice 3 may become unlikely due to the one-child policy, many parents who do not have sons may have to rely on professional care in the future, which usually requires a decent social security income. However, the results produced no such evidence.

One must consider that the implications above may be biased. Table 4 simply arranges the answers from the respondents, according to their gender. In reality, the respondents' attributes, such as age, income, educational background, and sibling status, may also influence the answer. The research needs a further investigation, controlling for these factors.

\section{Controlled Observations}

This section uses 5 explained and 10 explaining variables as seen in Table 5. Among them, the years of education of one's own/spouse's father and mother (5-8 in explaining variables) is a proxy variable for joining a pension program, which allows parents to be more independent from their children. As seen in Table 2, workers' pension participation rate in China is only 20.7 percent. The observations assume that higher education provides a better chance of participating in a pension program. 
Table 5: Variables and Description

\begin{tabular}{|c|c|}
\hline Variable & Description \\
\hline \multicolumn{2}{|l|}{ (Explained) } \\
\hline (1) I_care_own (dummy) & $\begin{array}{l}\text { Who will be the primary caregiver for your own parent(s) when } \\
\text { he/she (they) needs long-term care? }(1=\text { respondent, } 0=\text { others })\end{array}$ \\
\hline (2) I_care_spouse (dummy) & $\begin{array}{l}\text { Who will be the primary caregiver for your spouse's parent(s) } \\
\text { when he/she (they) needs long-term care? }(1=\text { respondent, } 0= \\
\text { others) }\end{array}$ \\
\hline $\begin{array}{l}\text { (3) Couple_care_own } \\
\text { (dummy) }\end{array}$ & $\begin{array}{l}\text { Who will be the primary caregiver for your own parent(s) when } \\
\text { he/she (they) needs long-term care? ( } 1=\text { respondent or } \\
\text { respondent's spouse, } 0=\text { others) }\end{array}$ \\
\hline $\begin{array}{l}\text { (4) Couple_care_spouse } \\
\text { (dummy) }\end{array}$ & $\begin{array}{l}\text { Who will be the primary caregiver for your spouse's parent(s) } \\
\text { when he/she (they) needs long-term care? ( } 1=\text { respondent or } \\
\text { respondent's spouse, } 0=\text { others) }\end{array}$ \\
\hline $\begin{array}{l}\text { (5) } \\
\text { Professiornal_care_own } \\
\text { (dummy) }\end{array}$ & $\begin{array}{l}\text { Who will be the primary caregiver for your own parent(s) when } \\
\text { he/she (they) needs long-term care? ( } 1=\text { Nursing home/Assisted } \\
\text { living home/Home helper, } 0=\text { others) }\end{array}$ \\
\hline \multicolumn{2}{|l|}{ (Explaining) } \\
\hline 1. Male_dummy & $1=$ male, $0=$ female \\
\hline 2. Age & Age \\
\hline 3. Education & Years of Education \\
\hline 4. E_spouse & Spouse's "Years of Education" \\
\hline 5. E_father & Father's "Years of Education" \\
\hline 6. E_mother & Mother's "Years of Education" \\
\hline 7. E_spouse_father & Spouse's father's "Years of Education" \\
\hline 8. E_spouse_mother & Spouse's mother's "Years of Education" \\
\hline 9. Income & Respondent's household income (yearly) \\
\hline 10. One_child_dummy & $1=$ no siblings, $0=$ have sibling(s) \\
\hline
\end{tabular}

Having five explained variables, this section has five estimation models:

(1) Prob $($ I_care_own $=1)=a+b$ (Male_dummy $)+c($ Age $)+d($ Education $)+e$ (Income $)+f($ One_child_dummy $)+g^{*} X(X$ : other explanatory variables $)$

If the hypothesis were right, sons would be more involved in parental care. 
Thus, the impact of Male_dummy would be positive. By contrast, if the hypothesis were wrong, daughters would be more involved in parental care. Thus, the impact of Male_dummy would be negative.

(2) Prob (I_care_spouse $=1)=a+b($ Male_dummy $)+c($ Age $)+d$ (Education) $+e$ (Income $)+f$ (One_child_dummy) $+g^{*} X$ ( $X$ : other explanatory variables)

This is the opposite of model (1). If the hypothesis were right, daughters would be more involved in the care for their spouses' parents. Thus, the impact of Male_dummy would be negative. By contrast, if the hypothesis were wrong, sons would be more involved in the care for their spouses' parents. Thus, the impact of Male_dummy would be positive.

(3) Prob (Couple_care_own $=1)=a+b$ (Male_dummy) $+c$ (Age) $+d$ $($ Education $)+e$ (Income $)+f$ (One_child_dummy) $+g^{*} X(X$ : other explanatory variables)

If the hypothesis were right, sons and their wives would be more involved in parental care. Thus, the impact of Male_dummy would be positive. By contrast, if the hypothesis were wrong, daughters would be more involved in parental care. Thus, the impact of Male_dummy would be negative.

(4) Prob (Couple_care_spouse $=1)=a+b$ (Male_dummy) $+c$ (Age) $+d$ (Education) $+e$ (Income $)+f$ (One_child_dummy) $+g^{*} X(X$ other explanatory variables)

Again, this is the opposite of model (3).

(5) Prob (Professional_care_own $=1)=a+b$ (Male_dummy) $+c($ Age $)+d$ $($ Education $)+e$ (Income $)+f$ (One_child_dummy) $+g^{*} X(X$ other explanatory variables)

If the hypothesis were right, the parents with pension programs would rely more on professional services. Since parents' dependency on their children causes the gender imbalance in China, the development of a social security 
system would decrease that dependency. As a result, Chinese gender imbalance at birth would be eased. Therefore, the impact of E_father and E_mother would be positive. Otherwise, the results would not support the logic drawn from the literature.

Table 6 depicts the descriptive statistics for the variable used in this analysis. Almost exactly half of the observations are male. Education ranges from a minimum of 3 years to the 16 years of a $\mathrm{PhD}$ candidature. As the average age of the respondents making the observations is 47.6 years old, many of them were born prior to 1979. As a result, only 13 percent of them are single children (no siblings).

Table 6: Descriptive Statistics

\begin{tabular}{|l|l|l|l|l|l|}
\hline (Explained) & Mean & Sd & Max & Min & Obs \\
\hline (1) I_care_own (dummy) & 0.515 & 0.500 & 1 & 0 & 454 \\
\hline (2) I_care_spouse (dummy) & 0.205 & 0.404 & 1 & 0 & 454 \\
\hline $\begin{array}{l}\text { (3) Couple_care_own } \\
\text { (dummy) }\end{array}$ & 0.586 & 0.493 & 1 & 0 & 454 \\
\hline $\begin{array}{l}\text { (4) Couple_care_spouse } \\
\text { dummy) }\end{array}$ & 0.564 & 0.496 & 1 & 0 & 454 \\
\hline $\begin{array}{l}\text { (5) Professiornal_care_own } \\
\text { (dummy) }\end{array}$ & 0.062 & 0.241 & 1 & 0 & 454 \\
\hline (Explaining) & & & & & \\
\hline 1. Male_dummy & 0.509 & 0.500 & 1 & 0 & 454 \\
\hline 2. Age & 47.218 & 11.316 & 70 & 24 & 454 \\
\hline 3. Education & 10.846 & 2.747 & 16 & 3 & 454 \\
\hline 4. E_spouse & 10.652 & 2.739 & 16 & 3 & 454 \\
\hline 5. E_father & 7.337 & 2.460 & 16 & 3 & 454 \\
\hline 6. E_mother & 6.828 & 2.465 & 16 & 3 & 454 \\
\hline 7. E_spouse_father & 7.073 & 2.463 & 16 & 3 & 454 \\
\hline 8. E_spouse_mother & 6.670 & 2.424 & 16 & 3 & 454 \\
\hline 9. Income & 5158.590 & 6012.691 & 90300 & 1400 & 454 \\
\hline 10. One_child_dummy & 0.143 & 0.351 & 1 & 0 & 454 \\
\hline
\end{tabular}

Table 7 summarizes the estimation results. Model 1 and Model 3 show that Male_dummy is positive and significant. Model 2 indicates that Male_dummy is negative and significant. In Model 4, Male dummy is also negative, but not significant. Overall, the results support the hypothesis. 
Table 7: Estimation Results

\begin{tabular}{|c|c|c|c|c|c|}
\hline & $\begin{array}{c}(1) \\
\text { I_care_own }\end{array}$ & $\begin{array}{c}\text { (2) } \\
\text { I_care_spouse }\end{array}$ & $\begin{array}{c}\text { (3) } \\
\text { Couple_care_own }\end{array}$ & $\begin{array}{c}\text { (4) } \\
\text { Couple_care_spouse }\end{array}$ & $\begin{array}{c}(5) \\
\text { Professional_care } \\
\text { own }\end{array}$ \\
\hline Male_dummy & $\begin{array}{l}0.286^{*} \\
(2.28)\end{array}$ & $\begin{array}{l}-0.240 \\
(-1.72)\end{array}$ & $\begin{array}{c}0.435^{* * *} \\
(3.37)\end{array}$ & $\begin{array}{c}-0.0724 \\
(-0.57)\end{array}$ & $\begin{array}{l}-0.140 \\
(-0.69)\end{array}$ \\
\hline Age & $\begin{array}{c}-0.0314^{* * *} \\
(-4.38)\end{array}$ & $\begin{array}{c}-0.0265^{* *} \\
(-3.28)\end{array}$ & $\begin{array}{c}-0.0402^{* * *} \\
(-5.36)\end{array}$ & $\begin{array}{c}-0.0403^{* * *} \\
(-5.43)\end{array}$ & $\begin{array}{c}0.0153 \\
(1.32)\end{array}$ \\
\hline Education & $\begin{array}{l}0.0480 \\
(1.24)\end{array}$ & $\begin{array}{c}0.0187 \\
(0.43)\end{array}$ & $\begin{array}{c}0.0445 \\
(1.09)\end{array}$ & $\begin{array}{c}0.0678 \\
(1.67)\end{array}$ & $\begin{array}{c}0.0274 \\
(0.43)\end{array}$ \\
\hline E_spouse & $\begin{array}{c}-0.00273 \\
(-0.07)\end{array}$ & $\begin{array}{c}-0.0254 \\
(-0.57)\end{array}$ & $\begin{array}{c}-0.0224 \\
(-0.54)\end{array}$ & $\begin{array}{c}-0.0501 \\
(-1.22)\end{array}$ & $\begin{array}{l}0.132^{*} \\
(2.08)\end{array}$ \\
\hline E_father & $\begin{array}{c}-0.0770 \\
(-1.59)\end{array}$ & $\begin{array}{c}0.00148 \\
(0.03)\end{array}$ & $\begin{array}{c}-0.0390 \\
(-0.75)\end{array}$ & $\begin{array}{c}-0.0190 \\
(-0.37)\end{array}$ & $\begin{array}{c}0.0245 \\
(0.33)\end{array}$ \\
\hline E_mother & $\begin{array}{l}0.0625 \\
(1.24)\end{array}$ & $\begin{array}{c}0.000179 \\
(0.00)\end{array}$ & $\begin{array}{c}0.0564 \\
(1.05)\end{array}$ & $\begin{array}{c}0.0360 \\
(0.68)\end{array}$ & $\begin{array}{c}-0.0568 \\
(-0.75)\end{array}$ \\
\hline E_spouse_father & $\begin{array}{c}-0.0168 \\
(-0.33)\end{array}$ & $\begin{array}{c}-0.0326 \\
(-0.56)\end{array}$ & $\begin{array}{c}-0.0197 \\
(-0.37)\end{array}$ & $\begin{array}{c}-0.0455 \\
(-0.85)\end{array}$ & $\begin{array}{c}0.0430 \\
(0.53)\end{array}$ \\
\hline $\begin{array}{l}\text { E_spouse_mothe } \\
\mathrm{r}\end{array}$ & $\begin{array}{c}-0.00196 \\
(-0.04)\end{array}$ & $\begin{array}{c}0.00408 \\
(0.07)\end{array}$ & $\begin{array}{r}-0.0249 \\
(-0.48)\end{array}$ & $\begin{array}{r}0.0245 \\
(0.47)\end{array}$ & $\begin{array}{r}-0.0716 \\
(-0.87)\end{array}$ \\
\hline Income & $\begin{array}{c}0.0000135 \\
(1.01)\end{array}$ & $\begin{array}{c}-0.00000622 \\
(-0.47)\end{array}$ & $\begin{array}{c}0.0000298 \\
(1.49)\end{array}$ & $\begin{array}{c}0.0000229 \\
(1.23)\end{array}$ & $\begin{array}{c}-0.00000220 \\
(-0.14)\end{array}$ \\
\hline one_child_dummy & $\begin{array}{l}0.107 \\
(0.55)\end{array}$ & $\begin{array}{c}0.0417 \\
(0.20)\end{array}$ & $\begin{array}{c}0.0696 \\
(0.34)\end{array}$ & $\begin{array}{l}0.257 \\
(1.25)\end{array}$ & $\begin{array}{l}0.251 \\
(0.92)\end{array}$ \\
\hline _cons & $\begin{array}{l}1.079 \\
(1.78)\end{array}$ & $\begin{array}{l}0.793 \\
(1.18)\end{array}$ & $\begin{array}{l}1.732^{* *} \\
(2.73)\end{array}$ & $\begin{array}{l}1.826^{* *} \\
(2.91)\end{array}$ & $\begin{array}{c}-3.647^{* * *} \\
(-3.70)\end{array}$ \\
\hline$N$ & 454 & 454 & 454 & 454 & 454 \\
\hline
\end{tabular}

$t$ statistics in parentheses

${ }^{*} p<0.05,{ }^{* *} p<0.01,{ }^{* * *} p<0.001$

Throughout Model 1 to 4, age is negative and significant. That is, the older the child, the less he/she is involved in a parent's care. As the average age of the respondents is over 47 years old, this is probably because older children cannot physically afford to serve as primary caregivers for their parents.

Contrary to the hypothesis, Model 5 shows that both E_father and E_mother do not substantially influence the reliance on the use of professional care. This may mean that social security does not necessarily decrease parents' dependency on their children. Thus, the results do not support the 
hypothesis that the development of social security eases the gender imbalance at birth.

In Model 5, E_spouse is uniquely positive and significant. The better educated the child's spouse, the more likely the parents are to use professional care services. This may be because educated spouses tend to work outside the home, rather than staying at home and taking care of parents-in-law.

\section{Conclusions}

This paper provides evidence about the possible cause of the problematic gender imbalance at birth in China. Much literature on this issue has proceeded to discussions based on the traditional assumption that Chinese sons are more involved in taking care of parents than Chinese daughters are, and thus, Chinese parents prefer sons. Yet, empirical evidence is lacking. This study first verified the assumption by using the "Preference Parameters Study in China 2011," which conducted face-to-face interviews of randomly selected individuals in six major cities. More specifically, the study used target population samples aged 20-70 years old, married, and with at least one living parent. Second, discussions in the literature have led to the argument that decreasing child dependency by developing social security may ease the gender imbalance at birth. Thus, the study tested the validity of the argument, investigating the above-mentioned data.

As a result, this paper first presents empirical evidence that Chinese sons (and their wives) are more likely, compared to daughters (and their husbands), to be primary caregivers for parents. The paper also reports the finding that parents' dependency on their children would not necessarily decrease with the development of social security, although that may be the case when a child has a highly educated spouse.

Although this study has obvious limitations in that the data were collected in six major cities only, the problematic nature of gender imbalance at birth and the lack of available empirical evidence demand that researchers begin to construct a better understanding of the causes and possible solutions to this troubling phenomenon. With that in mind, this paper contributes to that 
construction of knowledge and insight. 


\section{References}

Cabinet Office, Government of Japan. (2012). Kodomo kosodate hakusho (White Paper for Child and Parenting), Government of Japan (in Japanese).

Chan, C. L. W., Yip, P. S. F., Ng, E. H. Y., Ho, P. C., Chan, C. H. Y., \& Au, J. S. K. (2002). Gender selection in China: Its meanings and implications, Journal of Assisted Reproduction and Genetics, 19 (9), 426-430.

Chen, Y., Li, H., \& Meng, L. (2012). Parental Sex Selection and Missing Girls in China, mimeo., Institute of Social and Economic Research, Osaka University, Osaka, Japan.

Coale, A. (1991). Excess Female Mortality and the Balance of the Sexes in the population: An Estimate of the Number of 'Missing Females'. Population and development Review, 17, 517-23. doi:10.2307/1971953.

Colombo F., Llena-Nazal A., Mercier J., \& Tjadens F. (2011). Help Wanted? Providing and Paying for Long-Term Care, Paris, OECD Publishing.

Cooney, S., \& Di, J. (1999). Primary Family Caregivers of Impaired Elderly in Shanghai, China: Kin Relationship and Caregiver Burden, Research on Aging, 21, 739-761. doi:10.1177/0164027599216002.

Davis, D. S. (1993). Financial security of urban retires, Journal of Cross-Cultural Gerontology, 8, 179-195.

Hesketh, T., \& Xing Z. W. (2006). Abnormal sex ratios in human populations: Causes and consequences, PINAS, 103 (36), 13271-13275. doi: 10.1073/pnas.0602203103.

National Bureau of Statistics of China. (2010). China Populations \& Employment Statistics Yearbook 2010, China Statistics Press.

OECD. (2005). Long-Term Care for Older People, Paris,OECD Publishing. 
OECD. (2012). Pension at Glance Asia/Pacific, Paris, OECD Publishing.

Wei, S., \& Zhang, X. (2011). The Competitive Saving Motive: Evidence from Rising Sex Ratios and Saving Rates in China, Journal of Political Economy, 119, 511-564.

World Bank. (2012). Gender Statistics Highlights, 2012 World Development Report, Data retrieved August,1, 2012, from World DataBank database.

Zhan, H. J., \& Montgomery, R. J. V. (2003). Gender and elder care in China: The influence of filial piety and structural constraints, Gender \& Society, 17, 209-229. 